\title{
ANALISIS MODEL HUBUNGAN SIKAP DAN NORMA SUBJEKTIF DENGAN NIAT BERWIRAUSAHA PADA MAHASISWA UNIVERSITAS UDAYANA
}

\author{
Pande Made Agus Surya Wipraja ${ }^{1}$ \\ Putu Saroyeni Piartini ${ }^{2}$
}

\author{
1,2Fakultas Ekonomi dan Bisnis Universitas Udayana, Bali, Indonesia \\ email: suryaagus74@gmail.com
}

\begin{abstract}
ABSTRAK
Tujuan dari penelitian ini adalah untuk mengetahui niat berwirausaha Mahasiswamahasiswi Universitas Udayana. Populasi dan sampel penelitian ini adalah 450 mahasiswamahasiswi Universitas Udayana yang terdiri dari 6 fakultas yang mewakili bidang ekstanta dan sosial yaitu Fakultas Ekonomi dan Bisnis, Fakultas Sastra, Fakultas Hukum, Ilmu Pariwisata, Fakultas Pertanian serta Fakultas Kelautan dan Perikanan. Hasil analisis menemukan bahwa sikap berpengaruh positif dan signifikan terhadap niat berwirausaha dan norma subjektif berpengaruh positif dan signifikan terhadap niat berwirausaha. Dari penelitian ini dapat disimpulkan bahwa norma subjektif dan sikap berpengaruh terhadap niat berwirausaha, semakin meningkat niat berwirausaha maka norma subjektif dan sikap turut meningkat. Peneliti selanjutnya dapat menambahkan variabel-variabel lain seperti jenis kelamin dan lingkungan. Hal ini dimaksudkan untuk memperoleh kekuatan hubungan yang lebih jelas mengenai variabel-variabel yang benar mampu menjelaskan suatu niat berwirausaha dalam lingkungan institusi.
\end{abstract}

Kata kunci: Sikap, Norma Subjektif, Niat Berwirausaha

\section{ABSTRACT}

The purpose of this study was to determine the intention of entrepreneurship students of Udayana University. The population and sample of this study were 450 students of Udayana University which consisted of 6 faculties representing the external and social fields namely the Faculty of Economics and Business, Faculty of Literature, Faculty of Law, Tourism, Faculty of Agriculture and the Faculty of Marine and Fisheries. The results of the analysis found that attitudes have a positive and significant effect on entrepreneurial intentions and subjective norms have a positive and significant effect on entrepreneurial intentions. From this study it can be concluded that subjective norms and attitudes influence the intention of entrepreneurship, the more the intention of entrepreneurship increases, the subjective norms and attitudes also increase. The next researcher can add other variables such as gender and environment. This is intended to obtain the strength of a clearer relationship regarding the correct variables capable of explaining an entrepreneurial intention in an institutional environment.

Keywords: Attitudes, subjective norms, intention of entrepreneurship 


\section{PENDAHULUAN}

Studi awal pada saat wawancara dengan mahasiswa S1 FEB diungkapkan mahasiswa tidak membuka usaha adalah karena risiko terlalu besar, mencari pekerjaan yang pasti, kurangnya teman untuk membuka usaha dan kurangnya modal.Mc Clelannd (1976) dalam (Silvia,2013), mengemukakan bahwa suatu Negara dapat maju apabila $2 \%$ dari total penduduk suatu negara berprofesi sebagai entrepreneur. Di negara-negara kurang berkembang, lebih banyak pemerintah melihat kewiraswastaan sebagai cara untuk merangsang pembangunan ekonomi dan mengatasi tantangan ekonomi dan sosial yang serius. Selama beberapa dekade terakhir kewiraswastaan telah menjadi minat yang tumbuh bagi para peneliti dan pemerintah di seluruh dunia karena meningkatnya persaingan global, kemajuan teknologi yang cepat berubah, dan ekonomi pasar yang berkembang. . Survei Eurobarometer tentang Kewirausahaan melaporkan bahwa kurangnya pengalaman bisnis, kesulitan untuk meningkatkan modal awal, birokrasi, lingkungan ekonomi yang buruk dan "ketakutan akan kegagalan".

Moris, Lewis dan Sexton (1994) menemukan bahwa kegiatan berwirausaha memiliki dampak yang besar terhadap perekonomian dan juga memberikan kualitas hidup bagi warganya. Menurut Praag dan Versloot (2007), berwirausaha sering dikaitkan untuk merangsang pertumbuhan ekonomi, inovasi, pekerjaan dan kreasi usaha. Penelitian empiris juga mendukung hubungan positif antara aktivitas berwirausaha terhadap pertumbuhan ekonomi.

Fakultas Ekonomi dan Bisnis Universitas Udayana atau yang biasa disingkat FEB UNUD adalah salah satu fakultas ekonomi mengajarkan mata kuliah berwirausaha untuk mahasiswanya. FEB UNUD juga memiliki unit kegiataan mahasiswa yang bernama WIDA (wirausahaan muda), sebagai sarana yang memiliki minat berwirausaha dan tempat saling bertukar pikiran antar anggota dan juga pembinanya. Selain memiliki mata kuliah berwirausaha dan unit kegiataan WIDA FEB UNUD juga mempunyai acara Equitech yang diadakan setiap tahunnya.

Menurut penelitian Pratiwi (2009) cara untuk meningkatkan minat berwirausaha adalah dengan mengadakan layanan informasi karier dan mengadirkan life model. Menurut Susita (2017) Alasan kenapa wirausaha perlu ditingkatkan di Indonesia karena memperingan beban pemerintah baik dalam pengematan devisa, penyediaan lapangan kerja bagi angkatan kerja baru ataupun korban PHK perusahaan-perusahaan konglomerasi yang terus bertambah jumlahnya, maupun dalam meningkatkan efisiensi perekonomian nasional. Alasan yang sama juga berlaku di bali kususnya

Survai awal terhadap 12 orang yang terdiri dari 6 orang laki - laki dan 6 orang wanita melalui media social, mengungkapkan bahwa mahasiswa laki - laki hanya 1 orang yang menjawab tidak ingin menjadi wirausaha dan 5 orang/83,3\% menjawab ingin menjadi wirausaha sedangkan mahasiswi perempuan menjawab 2 orang tidak ingin menjadi wirausaha, 1 orang tidak mau memilih, 1 orang tidak tahu, 2 orang $/ 30.3 \%$ ingin menjadi wirausaha. Pada saat survey awal alasan mahasiswa tidak mau membuka usaha karena risikonya tinggi, kurangnya modal, mencari pekerjaan yang pasti. Sedangkan alasan mahasiswa membuka usaha karena lebih menyukai tantangan, waktu lebih fleksibel. 
Berwirausaha telah menjadi bagian penting untuk setiap negara karena pertumbuhan kegiatan berwirausaha akan membantu dalam menciptakan pekerjaan bagi masyarakat dan mengurangi tingkat pengangguran (Abdullah Azhar et al., 2010). Berwirausaha adalah pekerjaan, peningkatan kualitas hidup, gradasi sosial, pengurangan kemiskinan dan sebagainya (Scott dan Twomey, 1988). Perkembangan terakhir menunjukkan bahwa kewiraswastaan telah berkembang secara radikal selama dua dekade terakhir, sejauh akademisi dan pemerintahan semakin memperhatikan peran pengembangan berwirausaha dalam pengembangan pemuda menuju sikap berwirausaha (Lucky dan Olusegun, 2011). Peneliti meneliti topik ini karena ingin mengetahui minat mahasiswa Universitas Udayana.

Teori reasoned Action pertama kali diperkenalkan oleh Martin Fishbein dan Icek Ajzen pada tahun 1980. Teori reason action menjelaskan hubungan intensi dengan perilaku yang sepenuhnya berada dalam kontrol individu ( volitional behavior) sehingga asumsi dasar teori reason action adalah bahwa setiap individu sadar dalam membuat keputusan untuk melakukan atau tidak melakukan suatu perilaku. Intensi ditentukan oleh sikap dan norma subyektif. Teori ini diawali dengan kritik terhadap teori dan pengukuran sikap yang sering kali tidak tepat, yaitu tidak dapat memperkirakan perilaku yang akan timbul Sikap ini merupakan hasil pertimbangan untung dan rugi dari perilaku tersebut (outcome of the behavior). Theory of Reason Action ( TRA ) ini adalah teori yang cukup memadai dalam memprediksi tingkah laku minat untuk menjadi wirausaha.

Oleh karena itu pemahaman tentang niat seseorang untuk berwirausaha (entrepreneurial intention) dapat mencerminkan kecendrungan orang untukmendirikan usaha secara riil (Jenkins \& Johnson, 1997). Pada dasarnya pembentukan jiwa berwirausaha dipengaruhi oleh faktor internal dan eksternal (Priyanto, 2008). Selanjutnya dijelaskan bahwa niat berwirausaha mencerminkan komitmen seseorang untuk memulai usaha baru dan merupakan isu sentral yang perlu diperhatikan dalam memahami proses berwirausaha pendirian usaha baru.

Entrepreneurial intention atau niat berwirausaha dapat diartikan sebagai langkah awal dari suatu proses pendirian sebuah usaha yang umumnya bersifat jangka panjang (Lee \& Wong, 2004). Niat berwirausaha adalah representasi dari tindakan yang direncanakan untuk melakukan perilaku berwirausaha (Tubbs \& Ekeberg, 1991). Intensi berwirausaha dapat diartikan sebagai proses pencarian informasi yang dapat digunakan untuk mencapai tujuan pembentukan suatu usaha (Katz dan Gartner, 1988). Seperti yang dinyatakan oleh Krueger dan Carsrud (1993), intensi telah terbukti menjadi prediktor yang terbaik bagi perilaku berwirausaha. Andika dan Madjid (2012) niat berwirausaha mencerminkan komitmen seseorang untuk memulai usaha baru dan merupakan isu sentral yang perlu diperhatikan dalam memahami proses berwirausaha dalam pendirian usaha baru

Allport (1935) mendefinisikan sikap sebagai keadaan mental dan saraf dari kesiapan (readiness), yang terorganisasi melalui pengalaman, menyebabkan pengaruh dinamis yang mengarahkan respon individu pada semua objek dan situasi yang terkait. (Fishbein dan Ajzen, 2008) Mendenifisikan sikap (Atitude) sebagai jumlah dari afeksi (perasaan) yang dirasakan seseorang untuk menerima 
atau menolak suatu objek atau perilaku dan diukur dengan suatu prosedur yang menempatkan individual dalam skala evaluatif dua kutub, misalnya baik atau jelek; setuju atau menolak, dan lainnya. Wirausaha yaitu seseorang yang inisiator , innovator, creator dan organisator yang penting dalam suatu kegiatan usaha, yang dicirikan : (a) selalu mengamankan investasi terhadap resiko, (b) mandiri, (c) berkreasi menciptakan nilai tambah, (d) selalu mencari peluang, (d) berorientasi ke masa depan. Ciri-ciri dan watak berwirausaha antara lain : percaya diri keyakinan, ketidaktergantungan, individualistis, dan optimisme berorientasi pada tugas dan hasil. kebutuhan untuk berprestasi, berorientasi laba, ketekunan dan ketabahan, tekad kerja keras, mempunyai dorongan kuat, energetik dan inisiatif pengambilan resiko kemampuan untuk mengambil resiko yang wajar dan suka tantangan. kepemimpinan perilaku sebagai pemimpin, bergaul dengan orang lain, menanggapi saran-saran dan kritik keorisinilan inovatif dan kreatif serta fleksibel berorientasi ke masa depan pandangan ke depan, perspektif.

Menurut Sumadi (2017) setiap peningkatan sikap akan mengakibatkan itensi berwirausaha meningkat. Sikap-sikap tersebut dipercaya memiliki pengaruh langsung terhadap niat berprilaku dalam hal ini yaitu berwirausaha dan dihubungkan dengan norma subyektif dan kontrol berwirausaha. Yang (2013) memandang individu yang menunjukan sinyal positif terhadap berwirausaha, akan lebih memungkinkan untuk bertindak sebagai seorang pengusaha dan percaya bahwa berwirausaha bukanlah sekedar metode untuk bertahan hidup tetapi cara untuk mencapai aktualisasi diri. Rasli et al. (2013) berpendapat bahwa apabila seorang siswa tidak sepenuhnya menyadari bahwa berwirausaha sebagai suatu karir maka siswa tidak akan pernah mengembangkan sikap positif kearah itu dan justru siswa akan mengembangkan sikap positif terhadap alternatif karir yang lebih dipahami olehnya. Menurut Widayoko (2016) sikap dapat mempengaruhi niat seseorang untuk berwirausaha dari keputusan dia untuk mengambil resiko atau menghindarinya

Rahayu dkk. (2011) menemukan bahwa sikap berwirausaha berpengaruh positif terhadap niat berwirausaha mahasiswa FEB Brawijaya.Chong et al. (2005) menemukan sikap berwirausaha berpengaruh positif terhadap niat berwirausaha mahasiswi bisnis di Malaysia. Hasil penelitian dari Suharti dan Sirine (2011) juga menunjukan bahwa sikap berpengaruh positif dan signifikan terhadap niat berwirausaha.Hasil penelitian Winarsih (2014) sikap berwirausaha berpengaruh positif terhadap niat berwirausaha pada mahasiswa program studi pendidikan akutansi fakultas keguruan ilmu pendidikan Universitas Muhamadiyah Surakarta Angkatan 2011/2012. Menurut hasil penelitian Sabharawati (2017) sikap berwirausaha berpengaruh positif terhadap niat berwirausaha pada mahasiswa semester 5 kampus AMA YPK Yogyakarta.

Komponen sikap terhadap berwirausaha : 1. Komponen kognitif, yaitu komponen yang tersusun atas dasar pengetahuan atau informasi yang dimiliki seseorang tentang objek sikapnya, 2. Komponen afektif, yaitu komponen yang terdiri dari seluruh perasaan atau emosi seseorang terhadap suatu objek, terutama penilaian, yang bersifat evaluatif dan berhubungan erat dengan nilai-nilai kebudayaan atau system nilai yang dimilikinya, 3. Komponen konatif, yaitu merupakan 
kecenderungan seseorang untuk bertingkah laku yang berhubungan dengan objek sikapnya.

Norma subjektif atau Subjectif Form melibatkan tekanan sosial yang dirasakan oleh seseorang dari mayoritas orang yang penting baginya, yang mempertimbangkan apakah ia harus atau tidak harus melakukan perilaku tersebut (Ajzen \& Fishbein, 1980). Norma subjektif diukur dengan skala subjective norm (Ramayah \& Harun, 2005) dengan indikator keyakinan peran keluarga dalam memulai usaha, keyakinan dukungan teman dalam usaha, keyakinan dukungan dari dosen, keyakinan dukungan dari pengusaha-pengusaha yang sukses, dan keyakinan dukungan dalam usaha dari orang yang dianggap penting. Menurut Baron dan Byne (2003) norma subjektif adalah persepsi individu apakah orang lain akan mendukung atau tidak terwujudnya tindakan tersebut objek penelitian adalah niat. Individu merasa lebih tertekan untuk melakukan perilaku tertentu ketika mereka percaya bahwa penting rujukan sosial individu atau kelompok menyetujui atau menolak melakukan perilaku tertentu dan termotivasi untuk memenuhi harapan dari ajuan tersebut Malebana et al. (2015). Norma subyektif dapat dipandang sebagai persepsi bahwa 'referensi orang' menyetujui keputusan untuk menjadi pengusaha (Ajzen, 2001)

Pruett et al. 2009 menyimpulkan bahwa norma subyektif, yang merupakan pengalaman keluarga dan support dari orang lain yang telah memiliki usaha mampu menumbuhkan niat berwirausaha.Widayoko (2016) mengatakan norma subjektif yaitu keyakinan individu untuk mematuhi arahan atau anjuran orang disekitarnya untuk turut dalam melakukan aktifitas berwirausaha. Andika dan Madjid (2012) menyatakan bahwa norma subyektif berpengaruh secara signifikan terhadap intensi berwirausaha pada mahasiswa Fakultas Ekonomi Universitas Syiah Kuala.

Entrepreneurial intention atau niat berwirausaha dapat diartikan sebagai langkah awal dari suatu proses pendirian sebuah usaha yang umumnya bersifat jangka panjang (Lee \& Wong, 2004).Niat berwirausaha adalah representasi dari tindakan yang direncanakan untuk melakukan perilaku berwirausaha (Tubbs \& Ekeberg 1991). Intensi berwirausaha dapat diartikan sebagai proses pencarian informasi yang dapat digunakan untuk mencapai tujuan pembentukan suatu usaha (Katz \& Gartner, 1988). Seperti yang dinyatakan oleh Krueger dan Carsrud (1993), intensi telah terbukti menjadi prediktor yang terbaik bagi perilaku berwirausaha. Andika dan Madjid (2012) niat berwirausaha mencerminkan komitmen seseorang untuk memulai usaha baru dan merupakan isu sentral yang perlu diperhatikan dalam memahami proses berwirausaha dalam pendirian usaha baru. Menurut Nurshito dan Nugroho (2013), Niat berwirausaha adalah keadaan berfikir yang secara langsung dan mengarahkan perilaku individu ke arah pengembangan dan implementasi konsep bisnis yang baru. Niat adalah keinginan tertentu seseorang untuk melakukan sesuatu atau berapa tindakan, itu merupakan hasil dari pikiran sadar yang mengarahkan tingkah laku seseorang (Parker, 2014). Intensi telah menjadi prediktor terbaik bagi perilaku berwirausaha seseorang Jose (2010). Intensi berkaitan dengan indikasi akan seberapa susah seseorang mencoba untuk memahami seberapa besar usaha seseorang dalam merencanakan sesuatu, untuk melakukan sesuatu perilaku tertentu (Krithika \& Venkatachalam, 2014). 
Menurut Bygrave sifat-sifat wirausaha yaitu: 1. Dream, seorang wirausaha mempunyai visi bagaimana keinginannya terhadap massa depan pribadi dan bisnisnya termasuk kemampuan untuk mewujudkan mimpinya, 2. Decisveness, seorang wirausaha adalah orang yang tidak bekerja lambat, membuat keputusan yang cepat dengan penuh perhitungan dan ini merupakan kunci dalam kesuksesan usahanya, 3. Doers, begitu pelaku mengambil keputusan langsung ditindak lanjuti, dan tidak mau menunda kesempatan yang bisa dimanfaatkan, 4. Determination, dalam melaksanakan kegiatan penuh saksama. Rasa tanggung jawab yang dimiliki tinggi dan tidak mudah menyerah meski dihadapkan berbagai rintangan yang sulit, 5. Dedication, didikasinya sangat tinggi, dan terkadang lebih mementingkan bisnisnya dari pada keluarganya, 6 . Destiny, bertanggung jawab terhadap tujuan yang hendak dicapai, serta tidak tergantung terhadap orang lain dan memiliki kebebasan

$\mathrm{H}_{1}$ : Sikap berwirausaha berpengaruh positif signifikan terhadap niat berwirausaha

Pada penelitian Philips (2008) juga ditemukan bahwa norma subyektif berpengaruh positif terhadap niat berwirausaha siswa kursus manajemen di Amerika Serikat. Pada penelitian Sarwako (2011) dimana semakin tinggi dukungan pada mahasiswa maka semakin tinggi pula niat berwirausaha. Pada penelitian Rahayu dkk. (2011) ditemukan bahwa norma subyektif berpengaruh positif terhadap niat berwirausaha FE Universitas Brawijaya. Pada penelitian Jianfeng (2013) ditemukan bahwa norma subyektif berpengaruh positif terhadap niat berwirausaha siswa dan juga mahasiswa di tiongkok. Norma subjektif atau Subjectif Form melibatkan tekanan sosial yang dirasakan oleh seseorang dari mayoritas orang yang penting baginya, yang mempertimbangkan apakah ia harus atau tidak harus melakukan perilaku tersebut

$\mathrm{H}_{2}$ : Norma Subyektif berpengaruh positif terhadap niat kewirausaha

\section{METODE PENELITIAN}

Penelitian survei merupakan penelitian yang mengumpulkan informasi dari suatu sampel dengan menanyakan melalui angket atau interview supaya nantinya menggambarkan berbagai aspek dari populasi (Faenkel dan Wallen,1990). Lokasi penelitian ini dilakukan di Fakultas Ekonomi dan Bisnis Universitas Udayana di Bali

Subjek dalam penelitian ini adalah seluruh mahasiswa dan mahasiswi Universitas Udayana (Fakultas Ekonomi dan Bisnis, Fakultas Sastra, Fakultas Hukum, Fakultas Pariwisata, Fakultas Pertanian, Fakultas Perikanan) yang telah mengambil/ tidak mendapatkan mata kuliah kerwirausahaan. Objek penelitian adalah niat berwirausaha mahasiswa-mahasiswi Universitas Udayana (Fakultas Ekonomi dan Bisnis, Fakultas Sastra, Fakultas Hukum, Fakultas Pariwisata, Fakultas Pertanian, Fakultas Perikanan)

Variabel bebas dalam penelitian ini adalah sikap $\left(\mathrm{X}_{1}\right)$ dan norma subjektif (X2).Sikap menurut Fishbein dan Ajzen(1975), yaitu suatu predisposisi yang dipelajari untuk merespon secara positif atau negatif terhadap suatu obyek situasi, konsep dan orang.Norma subjektif juga dikenal dengan norma sosial mengacu pada tekanan sosial yang dirasakan untuk melakukan atau tidak melakukan perilaku yang diinginkan.Variabel terikat dalam penelitian ini adalah niat 
berwirusaha $\left(\mathrm{Y}_{1}\right)$. Niat berwirausaha dapat diartikan sebagai langkah awal dari suatu proses pendirian sebuah usaha yang umumnya bersifat jangka panjang (Lee \& Wong, 2004)

Sikap menurut Fishbein dan Ajzen (1975), yaitu suatu predisposisi yang dipelajari untuk merespon secara positif atau negatif terhadap suatu obyek situasi, konsep dan orang.Adapun indikator sikap berwirausaha adalah: 1) Saya mendapatkan sensasi terbesar saya saat pekerjaan saya yang terbaik ada. 2) Saya tidak pernah menaruh hal-hal penting sampai waktu yang lebih tepat. 3) Saya jarang mengikuti instruksi kecuali tugas yang sedang saya kerjakan terlalu rumit.4) Saya bekerja keras untuk menjadi yang terbaik di bidang saya. 5) Saya merasa gagal total ketika rencana bisnis saya tidak berubah seperti yang saya kira seharusnya. 6) Bekerja sama dengan rekan yang inovatif dalam bisnis yang dinamis.

Norma subjektif juga dikenal dengan norma sosial mengacu pada tekanan sosial yang dirasakan untuk melakukan atau tidak melakukan perilaku yang diinginkan. Adapun indikator norma subjektif adalah: 1) Ayah mengarahkan saya membuka usaha setelah lulus kuliah. 2) Ibu mengarahkan saya membuka usaha setelah lulus kuliah. 3) Kakek mengarahkan saya membuka usaha setelah lulus kuliah. 4) Nenek mengarahkan saya membuka usaha setelah lulus kuliah. 5) Kakak mengarahkan saya membuka usaha setelah lulus kuliah. 6) Adik mengarahkan saya membuka usaha setelah lulus kuliah. 7) Paman mengarahkan saya membuka usaha setelah lulus kuliah 8) Bibi mengarahkan saya membuka usaha setelah lulus kuliah .9) Teman-teman mengarahkan saya membuka usaha setelah lulus kuliah. 10)Dosen mengarahkan saya membuka usaha setelah lulus kuliah.

Niat berwirausaha dapat diartikan sebagai langkah awal dari suatu proses pendirian sebuah usaha yang umumnya bersifat jangka panjang (Lee \& Wong, 2004). Adapun indicator niat berwirausaha adalah : 1) Saya tertarik untuk menjadi seorang wirausaha. 2) Saya akan membuka usaha setelah saya lulus kuliah.

Data kuantitatif adalah data yang berbentuk angka atau dinyatakan dalam satuan tertentu. Data kuantitatif yang digunakan yang digunakan dalam penelitian ini adalah jumlah mahasiswa yang telah mengambil/ tidak mendapatkan mata kuliah berwirausaha di Universitas Udayana (Fakultas Ekonomi dan Bisnis, Fakultas Sastra, Fakultas Hukum, Fakultas Pariwisata, Fakultas Pertanian, Fakultas Perikanan). Data kualitatif adalah data yang tidak berbentuk angka atau dinyatakan dalam satuan ukuran tertentu. Data kualitatif yang digunakan di dalam penelitian ini meliputi norma subjektif sikap terhadap berwirausaha dengan niat berwirausaha pada mahasiswa-mahasiswi Fakultas Universitas Udayana (Fakultas Ekonomi dan Bisnis, Fakultas Sastra, Fakultas Hukum, Fakultas Pariwisata, Fakultas Pertanian, Fakultas Perikanan).

Sumber Primer data penelitian ini antara lain adalah survei yang dilakukan pada mahasiswa-mahasiswi Universitas Udayana studi kasus Fakultas Ekonomi dan Bisnis, Fakultas Sastra, Fakultas Hukum, Fakultas Pariwisata, Fakultas Pertanian, Fakultas Perikanan) yang berjumlah 450 orang. Sumber sekunder data penelitian ini adalah jumlah mahasiswa-mahasiswi yang telah mengambil mata 
kuliah berwirausaha di Universitas Udayana (studi kasus Fakultas Ekonomi dan Bisnis, Fakultas Sastra, Fakultas Hukum, Fakultas Pariwisata, Fakultas Pertanian, Fakultas Perikanan yang didapat dari bagian akademik fakultas).

Populasi penelitian ini adalah mahasiswa-mahasiswi di Universitas Udayana (studi kasus Fakultas Ekonomi dan Bisnis, Fakultas Sastra, Fakultas Hukum, Fakultas Pariwisata, Fakultas Pertanian, Fakultas Perikanan). Sampel penelitian ini adalah mahasiswa-mahasiswi Universitas Udayana (studi kasus Fakultas Ekonomi dan Bisnis, Fakultas Sastra, Fakultas Hukum, Fakultas Pariwisata, Fakultas Pertanian, Fakultas Perikanan yang telah mengambil matakuliah berwirausaha).

Dalam pengumpulan data yang diperlukan dalam penelitian ini, dilakukan dengan beberapa teknik, yaitu wawancara dan kuesioner. Wawancara, dilakukan dengan mengajukan beberapa pertanyaan kepada responden yang terpilih untuk memperjelas jawaban dalam kuisioner dan kepada pihak-pihak yang membantu penelitian dalam pengumpulan data, baik data primer maupun data sekunder. Kuisioner, dilakukan dengan menyebarkan daftar pertanyaan kepada para responden yang terpilih sebagai sampel penelitian.

Uji Validitas dalam penelitian ini menggunakan analisis faktor konfirmatori. Teknik ini digunakan untuk mengestimasi pengukuran model dan menguji undimensionalitas dari masing-masing model yaitu norma subjektif, sikap terhadap berwirausaha dan niat berwirausaha. Nilai Kaiser Meyer (KMO) menunjukan tingkat validitas dari analisis faktor konfirmatori. Instrument dapat dinyatakan valid jika bernilai factor loading item minimal $>0.4$, dengan nilai Keiser Olkin Meyer minimal 0.50, Commulative Explained Varience minimal $>0.50$ atau 50\% dan nilai Eigen factor minimal >1.0 (Hair et al., 1998:228). Jika telah sesuai dengan kriteria tersebut berarti persepsi dari responden terhadap butirbutir pertanyaan dari masing-masing variable dalam instrument penelitian dinyatakan valid

Uji Reliabilitas instrumen diukur berdasarkan nilai alpha cronbach. Ghozali (2006:85) menyatakan variabel yang dapat menyatakan reliabel apabila koefisien alpha cronchbach $=0,6$ artinya tingkat reliabilitas sama dengan dan lebih besar dari 0,6 merupakan indikasi reliabelnya sebuah konstruk.

Data multivariate tidak hanya terdiri atas satu variabel saja melainkan dapat terdiri atas lebih dari pada satu variabel. Misal data dari $n$ pengamatan pada $\mathrm{p}$ variabel sehingga dapat disusun matriks dengan $n$ baris dan $\mathrm{p}$ kolom, dinotasikan $\mathrm{X}$.

Karena dalam penelitian ini menggunakan statistic parametrik dengan modal regresi berganda, maka sebelumnya perlu dilakukan uji asumsi klasik yang meliputi Uji Normalitas, Uji Multikolinearitas, Uji Heteroskedastisitas.

Uji normalitas bertujuan untuk menguji apakah suatu data berdistribusi normal atau tidak.Pada prinsipnya normalitas dapat dideteksi dengan melihat penyebaran data (titik) pada sumbu diagonal dari grafik atau dengan melihat histogram dari residualnya.

Uji ini bertujuan untuk menguji apakah dalam model regresi ditemukan adanya korelasi antara variabel-variabel bebas.Model regresi yang baik mensyaratkan tidak ada masalah multikolinearitas. Salah satu cara untuk 
mendeteksi ada tidaknya multikolonearitas dengan cara melihat Tolerance dan VIF (Variance Inflation Faktor). Metode pengambilan keputusan yaitu semakin kecil nilai Tolerance dan semakin besar nilai VIF maka semakin mendekati terjadinya masalah multikolinearitas. Dalam kebanyakan penelitian menyebutkan bahwa jika Tolerance lebih dari 0,1 dan VIF kurang dari 10 maka tidak terjadi multikolinearitas (Priyatno,2011)

Uji heteroskedastisitas menurut (Ghozali, 2006) tujuan dari asumsi ini adalah menguji apakah dalam model regresi terjadi ketidaksamaan varian dari residual satu ke pengamatan yang lain tetap maka disebut homo kedisitas jika berbeda disebut heteroskeditisitas. Metode yang digunakan untuk menguji adanya heteroskeditisitas adalah uji Glesjer

Koefisien determinasi $\left(\mathrm{R}^{2}\right)$ digunakan untuk mengukur kemampuan model regresi dalam menerangkan variasi variabel bebas.Nilai koefisien determinasi adalah antara nol dan satu. Nilai $\mathrm{R}^{2}$ yang kecil berarti kemampuan variabelvariabel bebas memberiksan hampir semua informasi yang dibutuhkan untuk memprediksi variasi variabel terikat. Kelemahan mendasar penggunaan koefisien determinasi adalah bias terhadap jumlah variabel bebas yang dimasukkan ke dalam model. Setiap tambahan satu variabel bebas, maka $\mathrm{R}^{2}$ akan meningkat, tidak peduli apakah variabel tersebut berpengaruh signifikan terhadap variabel terikat. Nilai adjusted $\mathrm{R}^{2}$ dapat digunakan untuk mengevaluasi model regresi yang terbaik.

Uji statistik F digunakan untuk mengetahui kelayakan model regresi linear berganda sebagai alat analisis pengujian tentang pengaruh variabel bebas terhadap variabel terikat. Bila signifikan pada pada annova lebih kecil dari pada $\alpha=0,05$ maka model ini layak atau fit

Uji statistik digunakan untuk mengetahui pengaruh satu variabel bebas secara individual dalam menjelaskan variasi variabel terikat (Ghozali, 2006). Pengujian dilakukan dengan taraf signifikasi $\alpha=0,05$. Apabila tingkat signifikasi variabel bebas kurang dari tingkat signifikasi $\alpha=0,05$, maka dapat dikatakan bahwa variabel bebas berpengaruh signifikan terhadap variabel terikat.

\section{HASIL DAN PEMBAHASAN}

Kualitas data variabel penelitian dievaluasi validitas dan reliabilitasnyasebelum digunakan untuk pengujian hipotesis penelitian. Evaluasi validitas data penelitian menggunakan analisis faktor sementara evaluasi reliabilitas dilakukan dengan metode skala (scale methods).Kelayakan data variabel penelitian dianalisis dengan metode analisis faktor berdasarkan nilai kritis besaran parameter- parameter berikut yaitu: Keiser Meyer Olkin (KMO) $\geq 0,50$, Nilai Eigen $\geq 1,0$, Nilai Loading $\geq 0,5$ dan Nilai Total Variasi yang dijelaskan $\geq$ 0,51 . Standar nilai minimal reliabilitas data variabel penelitian ditetapkan berdasarkan parameter Alpha Cronbach $\geq 0,60$.

Kualitas data variabel norma yang dikumpulkan dalam penelitian ini dinyatakan memiliki validitas dan reliabilitas yang memadai ditunjukan oleh nilai parameter-parameter berikut yaitu:Kaiser Meyer Olkin $(\mathrm{KMO})=0,883$, dan Nilai Total Variasi yang dijelaskan $=55,382$. Berdasarkan nilai parameter uji faktor, hasil analisis faktor mengungkap bahwa dengan metode ekstraksi prinsipal 
kompenen analisis dari 10 indikator variabel normahanya terbentuk 1 faktor yang memiliki nilai eigen lebih besar dari 1,0.

Kualitas data variabel sikap yang dikumpulkan dalam penelitian ini dinyatakan memiliki validitas dan reliabilitas yang memadai ditunjukan oleh nilai parameter-parameter berikut yaitu: Kaiser Meyer Olkin $(\mathrm{KMO})=0,933$, dan Nilai Total Variasi yang dijelaskan $=44,526$. Data variabel sikap dinilai memiliki reliabilitas memadai dengan nilai parameter Alpha Cronbach $=0,914$. Hasil analisis faktor mengungkap bahwa dengan metode ekstraksi prinsipal kompenen analisis dari 23 indikator variabel sikap terbentuk 4 faktor yang memiliki nilai eigen lebih besar dari 1,0.Faktor yang membentuk dimensi sikap adalah faktor 1 , faktor 2, factor 3, dan factor 4 .

Kualitas data variabel niat berwirausaha yang dikumpulkan dalam penelitian ini dinyatakan memiliki validitas dan reliabilitas yang memadai ditunjukan oleh nilai parameter-parameter berikut yaitu: Kaiser Meyer Olkin $(K M O)=0,500$, dan Nilai Total Variasi yang dijelaskan $=86,160$. Data variabel niat berwirausaha dinilai memiliki reliabilitas memadai dengan nilai parameter Alpha Cronbach $=0,838$. Hasil analisis faktor mengungkap bahwa dengan metode ekstraksi prinsipal kompenen analisis dari 2 indikator variabel niat berwirausaha hanya terbentuk 1 faktor yang memiliki nilai eigen lebih besar dari 1,0.

Setelah kuesioner dinyatakan valid pada pengukuran validitas, selanjutnya dilakukan pengujian reliabilitas. Reliabilitas merupakan alat untuk mengukur apakah kuesioner yang digunakan andal. Suatu alat ukur disebut mempunyai reliabilitas tinggi atau dapat dipercaya jika alat ukur itu mantap dalam pengertian alat ukur tersebut stabil,dapat diandalkan,dan dapat diramalkan. Pengujian reliabilitas dalam penelitian ini menggunakan cronbach alpha $(\alpha)$. Koefisien cronbach alpha yang lebih dari 0,70 menunjukkan keandalan (reliabilitas) instrumen. Selain itu, nilai koefisien cronbachalpha yang semakin mendekati 1 menunjukkan semakin tinggi konsistensi internal reliabilitasnya. Di dalam pengujian reliabilitas penulis menggunakan bantuan SPSS 13.0. Hasil uji Reliabilitas variabel penelitian disajikan pada Tabel 1.

Tabel 1.

Hasil Uji Reliabilitas Variabel Penelitian

\begin{tabular}{lccc}
\hline \multicolumn{1}{c}{ Variabel } & Croncbach Alpha & SandarReliabilitas & Keterangan \\
\hline Inten & 0,838 & 0,700 & Reliabel \\
BisATT & 0,914 & 0,700 & Reliabel \\
\hline
\end{tabular}

Sumber:Data primer diolah, 2018

Tabel 1. menunjukkan bahwa nilai cronbachalpha( $\alpha$ ) untuk masing- masing variable adalah lebih dari 0,70 . Dengan demikian dapat disimpulkan bahwa butirbutir pernyataan kuesioner dalam setiap variable adalah reliabel (dapat diandalkan).

Uji Reliabilitas terhadap instrumen penelitian ini menggunakan nilai Alpha Cronbach, yakni untuk mengetahui unidimensionalitas butir-butir pernyataan terhadap variabel laten yang diteliti. Nilai Alpha Cronbach dinyatakan reliabel jika nilainya lebih besar atau sama dengan 0,60. Rekapitulasi hasil uji reliabilitas instrumen penelitian dapat dilihat pada Tabel berikut. 
Tabel 2.

Rekapitulasi Hasil Uji Reliabilitas Instrumen Penelitian

\begin{tabular}{cccc}
\hline No. & Form & Cronbach's Alpha & Keterangan \\
\hline $\mathbf{1}$ & Pernyataan dalam Form 2 & 0,750 & Reliabel \\
$\mathbf{2}$ & Pernyataan dalam Form 3 & 0,726 & Reliabel \\
$\mathbf{3}$ & Pernyataan dalam Form 4 & 0,736 & Reliabel \\
$\mathbf{4}$ & Pernyataan dalam Form 5 & 0,752 & Reliabel \\
\hline
\end{tabular}

Sumber : Data primer diolah, 2018

Hasil uji reliabilitas yang disajikan dalam Tabel 2. menunjukkan bahwa seluruh instrumen penelitian memiliki koefisien Cronbach's Alpha lebih dari 0,60. Jadi dapat dinyatakan bahwa seluruh variabel telah memenuhi syarat reliabilitas atau kehandalan sehingga dapat digunakan untuk melakukan penelitian.

Data karakteristik responden merupakan data yang dikumpulkan untuk mengetahui profil responden penelitian. Dari penelitian yang dilakukan pada 450 Mahasiswa Universitas Udayana. Kuesioner yang telah terkumpul, selanjutnya diperiksa untuk memastikan kelengkapan kuesioner yang telah diisi responden. Hasil pemeriksaan menunjukkan seluruh kuesioner dapat diikutsertakan dalam analisis, karena pengisiannya telah lengkap.

Dalam deskripsi variabel akan diuraikan persepsi responden terhadap variabel Sikap, Norma Subjektif dan Niat Berwirausaha untuk menetapkan penilaian secara kuantitatif menggunakan skala interval dengan mengintregasikan rata-rata skor menurut kategori penilaiannya.

Diketahui :

$$
\text { Rumus (Interval Kelas) }=\frac{\text { Range }}{\text { Jumlla } \text { klasifikasi }}
$$

$\mathrm{R}=$ Selisih antara nilai tertinggi dan nilai terendah $5-1=4$

$\mathrm{K}=$ Jumlah Klasifikasi $=5$

Perhitungan

$$
\mathrm{C}(\text { Interval Kelas })=\frac{4}{5}==0.8
$$

Maka dari hasil ini diketahui batas-batas klasifikasi (kriteria) dengan kategori penilaian seperti pada Tabel 3. sebagai berikut :

Tabel 3.

Kriteria Penilaian Jawaban Kuesioner Sikap, Norma Subjektif dan Niat Berwirausaha

\begin{tabular}{cc}
\hline Kriteria & Kategori Penelitian \\
\hline $1,00-1,80$ & Sangat tidak baik \\
$1,81-2,60$ & Kurang baik \\
$2,61-3,40$ & Cukup Baik \\
$3,41-4,20$ & Baik \\
$4,21-5,00$ & Sangat Baik \\
\hline
\end{tabular}

Sumber:Data primer diolah, 2018 
Deskripsi data tanggapan responden terhadap Sikap yang disebarkan kepada 450 orang responden dengan 73 pernyataan pada mahasiswa-mahasiswi Universitas Udayana ditanggapi menggunakan lima poin Skala Likert.

Deskripsi data tanggapan responden terhadap Sikap yang disebarkan kepada 450 orang responden dengan 73 pernyataan pada mahasiswa-mahasiswi Universitas Udayana ditanggapi menggunakan lima poin Skala Likert.Berdasarkan hasil penelitian, terlihat bahwa rata-rata skor dari 73 pernyataan mengenai sikap terhadap berwirausaha yaitu sebesar 3,043 yang berada di kisaran 2,61-3,40 yang berarti cukup baik pada mahasiswa-mahasiswi Universitas Udayana dari 73 indikator menyatakan bahwa Saya tampil sangat baik dalam proyek bisnis saya 3,54. Sedangkan, pernyataan Saya percaya penting untuk terus mencari cara baru untuk melakukan sesuatu dalam bisnis mendapat tanggapan yang terendah dengan nilai rata-rata 2,54. Berdasarkan hasil tersebut, sikap terhadap berwirausaha yang paling menonjol adalah bisnis harus sesuai dengan hukum pada mahasiswa-mahasiswi Universitas Udayana

Deskripsi data tanggapan responden terhadap Norma Subjektif yang disebarkan kepada 450 orang responden dengan 10 pernyataan pada mahasiswamahasiswi Universitas Udayana, diukur dengan menggunakan 10 pernyataan yang ditanggapi menggunakan 5 poin Skala Likert. Berdasarkan hasil penelitian, terlihat bahwa rata-rata skor dari 10 pernyataan mengenai Norma Subjektif yaitu sebesar 2,989 yang berada di kisaran 2,6-3,40 yang berarti Cukup baik pada mahasiswa-mahasiswi Universitas Udayana. Selain itu, dapat disampaikan bahwa pernyataan memperoleh tanggapan tertinggi Ibu mengarahkan saya membuka usaha setelah lulus kuliah, sedangkan pernyataan Paman mengarahkan saya membuka usaha setelah lulus kuliah dan Bibi mengarahkan saya membuka usaha setelah lulus kuliah mendapat kan nilai rata terendah sebesar 2,84.

Deskripsi data tanggapan responden terhadap niat berwirausaha yang disebarkan kepada 500 orang responden dengan 2 pernyataan pada mahasiswamahasiswi Universitas Udayana. Berdasarkan hasil penelitian, terlihat bahwa ratarata skor dari 2 pernyataan mengenai Niat Berwirausaha yaitu sebesar 2,938 yang berada di kisaran 2,61-3,40 yang berarti cukup baik pada mahasiswa-mahasiswi Universitas Udayana.Diinformasikan bahwa indikator Saya tertarik untuk menjadi seorang wirausaha memperoleh respon tertinggi dengan nilai rata-rata sebesar 3,229 . sedangkan indikator Saya akan membuka usaha setelah saya lulus kuliah memperoleh respon terendah dengan nilai rerata sebesar 2,647.

Model regresi dikatakan model yang baik apabila dalam model tersebut bebas dari asumsi klasik statistik. Suatu model regresi linier berganda secara teoritis akan menghasilkan nilai parameter penduga yang tepat bila memenuhi persyaratan asumsi klasik regresi, yaitu: uji normalitas, multikolinearitas, dan heteroskedastisitas. Hasil pengujian asumsi klasik yang diperoleh dalam penelitian ini adalah sebagai berikut :

Pengujian normalitas distribusi data sampel dilakukan dengan menggunakan statistic klomogorov-Smirnov. Data sampel dikatakan berdistribusi normal jika koefisien Asymp. Sig (2-tailed) lebih besar dari $\alpha=5 \%$.

Uji heteroskedastisitas dilakukan untuk mengatahui apakah dalam model regresi terjadi ketidaksamaan varians dari residual satu pengamatan ke 
pengamatan lain. Dari pengolahan data yang dilakukan dengan SPSS menunjukkan hasil yang dapat dilihat pada Tabel 4. dibawah ini :

Tabel 4.

Hasil Uji Hteroskedastisitas

\begin{tabular}{|c|c|c|}
\hline Model & $\mathbf{T}$ & \\
\hline (Constant) & 1,823 & ,069 \\
\hline Sikap & 11,165 &, 000 \\
\hline Norma & 5,101 &, 000 \\
\hline
\end{tabular}

Sumber:Data primer diolah, 2018

Model regresi dikatakan tidak terjadi masalah heteroskedastisitas jika variabel independen memiliki nilai probabilitas signifikansi di atas kepercayaan 5\%. Pada Tabel 4sikap kerja memiliki nilai signifikansi $0,00>0,05$. Begitupula dengan variabel norma subjektif memiliki nilai signifikansi $0,00>0.05$ maka disimpulkan model regresi t terkena masalah heteroskedastisitas.

Uji multikolinearitas dilakukan untuk mengatahui ada tidaknya hubungan linear diantara variabel bebas dalam model regresi. Dari pengolahan data yang dilakukan dengan SPSS menunjukkan hasil yang dapat dilihat pada tabel 5 dibawah ini :

Tabel 5.

Hasil Pengujian Multikolinearitas Variabel Sikap $\left(\mathbf{X}_{1}\right)$, Norma Subjektif $\left(\mathbf{X}_{2}\right)$, dan Niat Berwirausaha (Y)

\begin{tabular}{|c|c|c|c|}
\hline \multirow[t]{2}{*}{ Model } & \multicolumn{3}{|c|}{ Collinearity Statistics } \\
\hline & Tolerance & & \\
\hline 1 & & & \\
\hline $\begin{array}{c}\text { Sikap } \\
\text { Norma Subiektif }\end{array}$ & & ,895 & 1,117 \\
\hline
\end{tabular}

Sumber:Data primer diolah, 2018

Model regresi dikatakan tidak terjadi masalah multikolinearitas jika Tolerance lebih dari 0.10 dan VIF kurang dari 10. Pada Tabel 5. variabel sikap dan norma subjektif sama-sama memiliki nilai Tolerance $0,895>0.1$ dan begitupula sama-sama memiliki nilai VIF $1,117<10$ maka disimpulkan model regresi tidak terkena multikolinieritas

Metode analisis regresi linier berganda digunakan untuk mengetahui pengaruh/hubungan antara variabel independen (sikap dan norma subjektif ) terhadap variabel dependen (niat berwirausaha).Adapun rumus yang digunakan untuk mengetahui analisis regresi linier berganda dalam penelitian ini adalah menggunakan rumus sebagai berikut

$$
Y=a+\beta_{1} X_{1}+B_{2} X_{2}
$$

Keterangan:

$\mathrm{a}=$ Konstanta

$\beta=$ Koefisien regresi

$\mathrm{Y}=$ Variabel terikat yaitu Niat Berwirausaha

$\mathrm{X}_{1}=$ Variabel bebas yaitu Sikap

$\mathrm{X}_{2}=$ Variabel bebas yaitu Norma Subjektif 
Hasil dari analisis regresi linier berganda yang dihasilkan persamaan sebagai berikut :

$$
\mathrm{Y}=1,088+0,108 \times 1-0,033 \times 2
$$

Konstanta $=1,088$ artinya bahwa jika seluruh variabel independen Sikap dan Norma Subjektif dianggap konstan maka tingkat variabel Niat Berwirausaha (Y) sebesar 1,088.

Koefisien regresi Sikap $\left(\mathrm{X}_{1}\right)=0.108$ artinya jika variabel sikap meningkat, sedangkan variabel norma subjektif dianggap konstan/tetap, maka akan menaikkan sebesar 0,108.

Koefisien regresi norma subjektif $\left(\mathrm{X}_{2}\right)=-0,0322$ artinya jika variabel norma subjektif ditingkatkan sebesar satu satuan, sedangkan variabel Sikap dianggap konstan/tetap, maka akan menurunkan niat berwirausahasebesar 0,0322 .

Adapun tabel rekapitulasi hasil analisis regresi linier berganda terkait hubungan sikap dan norma subjektif terhadap niat berwirausaha adalah sebagai berikut:

Tabel 6.

Hasil Analisis Regresi Linear Berganda

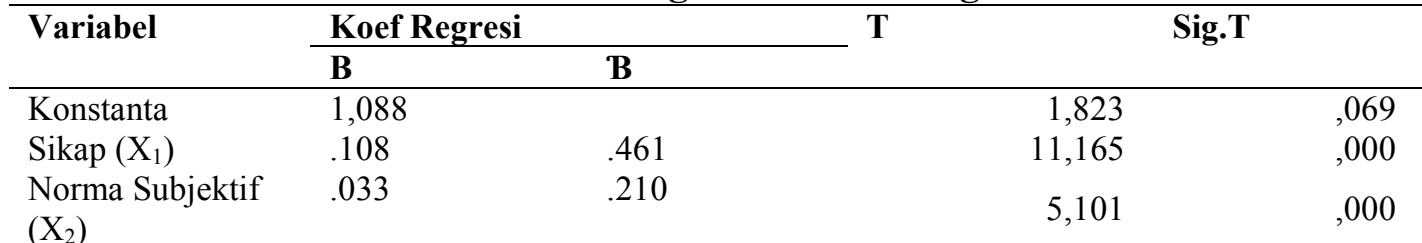

$\left(\mathrm{X}_{2}\right)$

Fhitung=104,724

rKorelasi $=.565$

$\mathrm{SigF}=.000$

Variabel Terikat :Niat Berwirausaha $=$

Sumber:Data primer diolah, 2018

Berdasarkan rekapitulasi hasil analisis yang tersaji dalam Tabel 6. di atas, maka dapat disampaikan bahwa variabel Sikap $\left(\mathrm{X}_{1}\right)$, dan variabel Norma Sujektif $\left(\mathrm{X}_{2}\right)$, memiliki hubungan terhadap Niat Berwirausaha(Y). Hasil ini ditunjukkan pada koefisien korelasi yang benilai positif sebesar 0,565 .

Untuk meyakinkan model persamaan regresi yang dihasilkan dalam memprediksi, perlu melakukan pengujian kesesuaian (fit) model. Hasil pengujian kesesuaian model menggunakan koefisien adj $\mathrm{R}^{2}$ sebesar 0.319 yang berarti bahwa sebesar 31,9\% niat berwirausaha pada mahasiswa-mahasiswi Universitas Udayana dipengaruhi oleh sikap dan Norma Subjektif. Sedangkan sisanya sebesar 68,10\% dipengaruhi atau diprediksi variabel-variabel lain yang tidak ada dalam model dan variabel error.

Karena angka koefisien korelasi 0,565 berada dibawah 0,60. Ini berarti terdapat hubungan positif yang cukup kuat antara variabel sikap $\left(\mathrm{X}_{1}\right)$ dan variabel norma sikap $\left(\mathrm{X}_{2}\right)$ terhadap niat berwirausaha (Y).Informasi lain yang dapat diungkap dari hasil penelitian ini adalah peran variabel norma subjektif $\left(\mathrm{X}_{1}\right)$ yang dominan mendorong mahasiswa-mahasiswi untuk berniat berwirausaha pada Universitas Udayana. Temuan ini ditunjukkan pada koef. Regresi Beta $\left(\beta_{2}\right)$ sebesar 11,165. Sedangkan, variabel norma sujektif $\left(\mathrm{X}_{2}\right)$, memperoleh koef. 
Regresi Beta $\left(\beta_{2}\right)$ sebesar 5,101. Temuan ini menandakan norma =]ubjektif berperan penting dalam niat berwirausaha.

Untuk menguji nyata tidaknya pengaruh variabel stres kerja $\left(\mathrm{X}_{1}\right)$ dan norma subjektif $\left(\mathrm{X}_{2}\right)$ terhadap variabel terikat niat berwirausaha $(\mathrm{Y})$ maka dilakukan pengujian hipotesis yang diajukan dalam penelitian ini.

Sikap $\left(\mathrm{X}_{1}\right)$ berpengaruh positif terhadap niat berwirausaha(Y). Hasil ini ditunjukkan oleh koefisien regresi yang bernilai positif sebesar 0,108 dengan $\mathrm{T}$ statistic $=11,165$ dan signifikansi $(\mathrm{p})=0,000$, sehingga hipotesis-1 $\left(\mathrm{H}_{1}\right)$ diterima dan dapat dibuktikan secara empiris. Hasil menunjukan, semakin tinggi sikap berwirausaha yang dimiliki mahasiswa-mahasiswi, maka niat berwirausaha pada mahasiswa-mahasiswi Universitas Udayana semakin meningkat.

Norma subjektif berpengaruh positif terhadap niat berwirausaha(Y). Hasil ini ditunjukkan oleh koefisien regresi yang bernilai 0.033 dengan T-statistic= 5.101 dengan signifikansi $(\mathrm{p})=0,000$,sehingga hipotesis-2 $\left(\mathrm{H}_{2}\right)$ diterima. Hasil memberikan arti, semakin tinggi norma subjektif maka niat berwirausaha pada mahasiswa-mahasiswi Universitas Udayana semakin tinggi.

Dari hasil penelitian yang diperoleh, maka dapat dilakukan pembahasan berdasarkan hasil tersebut, sebagai berikut :

Pengaruh sikap $\left(\mathrm{X}_{1}\right)$ terhadap niat berwirausaha(Y) adalah signifikan, memiliki hubungan yang kuat dan bernilai positif (searah) dengan niat berwirausaha mahasiswa-mahasiswi Universitas Udayana. Hasil ini ditunjukkan oleh koefisien regresi yang bernilai positif sebesar 0,108 dengan T-statistic = 11,165 dengan signifikansi $(p)=0,000$ yaitu lebih kecil dari 0,05 . Hasil ini mengandung arti bahwa semakin sikap meningkat semakin niat berwirausaha meningkat. Untuk itu hipotesis yang diajukan dalam penelitian yang menyatakan semakin Sikap meningkat semakin niat berwirausaha meningkat pada mahasiswamahasiswi Universitas Udayana "diterima".

Diterimanya hipotesis penelitian yang diajukan dalam penelitian ini sesuai dengan teori sebagaimana diungkapkan oleh Menurut Sumadi (2017) setiap peningkatan sikap akan mengakibatkan itensi berwirausaha meningkat. Sikapsikap tersebut dipercaya memiliki pengaruh langsung terhadap niat berprilaku dalam hal ini yaitu berwirausaha.Dari uraian tersebut, maka niat berwirausaha mahasiswa-mahasiswi akan meningkat jika karyawan memiliki sikapyang tinggi menyebabkan mahasiswa-mahasiswi bersemangat untuk berwirausaha.

Hasil ini sesuai dengan penelitian sebelumnya yang dilakukan Rahayu dkk (2011) menemukan bahwa sikap berwirausaha berpengaruh positif terhadap niat berwirausaha mahasiswa FEB Brawijaya. Chong et al. (2005) menemukan sikap berwirausaha berpengaruh positif terhadap niat berwirausaha mahasiswi bisnis di Malaysia. Hasil penelitian Winarsih (2014) sikap berwirausaha berpengaruh positif terhadap niat berwirausaha pada mahasiswa program studi pendidikan akutansi fakultas keguruan ilmu pendidikan Universitas Muhamadiyah Surakarta Angkatan 2011/2012. Menurut hasil penelitian Sabharawati (2017) sikap berwirausaha berpengaruh positif terhadap niat berwirausaha pada mahasiswa semester 5 kampus AMA YPK Yogyakarta yang sama-sama menyatakan sikap berpengaruh positif dengan niat berwirausaha. 
Pengaruh norma subjektif $\left(\mathrm{X}_{2}\right)$ terhadap niat berwirausaha $(\mathrm{Y})$ adalah signifikan, memiliki hubungan yang lemah dan bernilai positif dengan niat berwirausaha. Hasil ini ditunjukkan oleh koefisien regresi yang bernilai positif sebesar 0,033 dengan T-statistic $=5,101$ dengan signifikansi $(\mathrm{p})=0,000$ yaitu lebih kecil dari 0,05.Hasil ini mengandung arti bahwa semakin tinggi norma subjektif semakin niat berwirausaha meningkat. Untuk itu hipotesis yang diajukan dalam penelitian yang menyatakan semakin tinggi norma subjektif semakin tinggi niat berwirausaha dengan begitu hipotesis "diterima"

Hasil ini sesuai dengan Pruett et al.2009, (dalam Engle et al. 2010) menyimpulkan bahwa norma subyektif, yang merupakan pengalaman keluarga dan support dari orang lain yang telah memiliki usaha mampu menumbuhkan niat berwirausaha.Widayoko (2016) mengatakan norma subjektif yaitu keyakinan individu untuk mematuhi arahan atau anjuran orang disekitarnya untuk turut dalam melakukan aktifitas berwirausaha. Andika dan Madjid (2012) menyatakan bahwa norma subyektif berpengaruh secara signifikan terhadap intensi berwirausaha pada mahasiswa Fakultas Ekonomi Universitas Syiah Kuala. yang sama-sama menyatakan norma subjektif berpengaruh positif dengan niat berwirausaha.

\section{SIMPULAN}

Pengaruh sikap terhadap niat berwirausaha Pengaruh sikap $\left(\mathrm{X}_{1}\right)$ berpengaruh positif terhadap niat berwirausaha $(\mathrm{Y})$. Artinya semakin tinggi sikap seseorang terhadap berwirausaha mahasiswa-mahasiswi semakin tinggi niat berwirausaha mahasiswa-mahasiswi Universitas Udayana.2)Pengaruh norma subjektif terhadap niat berwirausahaPengaruh norma subjektif $\left(\mathrm{X}_{2}\right)$ berpengaruh positif terhadap niat berwirausaha(Y). Artinya, semakin tinggi norma subjektif semakin tinggi niat berwirausaha mahasiswa-mahasiswi Universitas Udayana

Berdasarkan simpulan dari hasil penelitian dan pembahasan seperti yang telah dikemukakan sebelumnya, maka saran yang dapat diberikan oleh Penulis adalah sebagai berikut: 1) mahasiswinya terhadap niat berwirausaha melalui bimbingan/konseling. 2)Kepada peneliti selanjutnya Kepada pihak-pihak yang nantinya berkeinginan untuk meneliti kembali niat berwirausaha diharapkan untuk menambah variabel lain selain sikap dan norma subjektif yaitu seperti lingkungan dan jenis kelamin, . Hal ini dimaksudkan untuk memperoleh kekuatan hubungan yang lebih jelas mengenai variabel-variabel yang benar-benar mampu menjelaskan suatu niat berwirausaha dalam lingkungan sekolah.3)Kepada pihak Universitas Udayana. 3)Pihak Universitas Udayana bisa membantu mahasimahasiswinya dalam mengembangkan sikap mahasiswa

\section{REFERENSI}

Ajzen, I. (2008). Attitudes and the Prediction of Behavior. Published in: Attitudes and attitude change. Psychology, (July), 289-311.

Ajzen, I., \& Fisbein, M. (1975). Belief, Attitudes, Intention and Behavior An Introduction to Theory and Research. 
Ajzen, I., \& Fisbein, M. (1980). Understanding Attitudeses and Predicting Social Behavior. NJ: Practice-Hall.

Allport, G. W. (1935). Attitudes, In C. Murchison (Ed), A Handbook of social psychology Worchester. Mass: Clark University Press.

Andika, M., \& Madjid, I. (2012). Analisis Pengaruh Sikap, Norma Subyektif Dan Efikasi Diri Terhadap Intensi Berwirausaha Pada Mahasiswafakultas Ekonomi Universitas Syiah Kuala (Studi Pada Mahasiswa Fakutas Ekonomi Universitas Syiah Kuala). Eco Enterpreneurship Seminar \& Call for Paperrs "Improving Perfomance by Improving Perfomance by Improving Environment.

Azhar, A., Javaid, A., Rehman, M., \& Hyder, A. (2014). Entrepreneurial Intentions among Business Students in Pakistan. Journal of Law and Governance, 5(2), 13-21. https://doi.org/10.15209/jbsge.v5i2.181

Baron, \& Byrne. (2003). Psikologi Sosial.Jilid 1. Edisi Kesepuluh. Jakarta: Erlangga.

Campo, J. L. M. (2010). Analysis of the Influence of Self-efficacy on Entrepreneurial Intentions Análisis de la influencia de la auto-confianza en las intenciones emprendedoras. International Journal Julio - Diciembre De, 9(2), 14-21.

Choy, C. S., Kuppusamy, J., \& Jusoh, M. (2015). Entrepreneurial Careers Among Business Graduates: Match- Making Using Theory Of Planned Behavior. International Journal of Enterpreneurship, 9(1), 67-91.

Fraenkel, J. R., \& Wallen, N. E. (1990). How to Design and Evaluate Research in Education USA. San Fransisco: San Fransisco State University.

Ghozali, I. (2006). Aplikasi Analisis Multivariate Dengan Program SPSS. Cetakan Keempat. Semarang: Badan Penerbit Universitas Diponegoro.

Hair. (1998). Multivariate Data Analysis, Fifth Edition (Vol. 5). Prentice Hall: Upper Saddle.

Jenkins, M., \& Johnson, G. (1997). Entrepreneurial Intentions and Outcomes: A Comparative Causal Mapping Study. Journal Management Studies, 34(1), 895-920.

Katz, J., \& W. Gartner. (1988). Properties of Emerging Organizations. Academy of Management Review, 13(3), 429-441.

Krithika, \& Venkatachalam, B. (2014). A Study on Impact Of Subjective Norms 
OnEntrepreneurial Intention Among The Business Students In Bangalore. Journal of Business and Management, 16(5), 48-50.

Krueger, N. ., \& Carsrud, L. A. (1993). Enterprenurial Intentions: Applying the Theory of Planned Behavior. Enterpreneurship \& Regional Development, 5(4), 315-330.

Lee, S. H., \& Wong, P. K. (2004). An Exploratory Study of Technopreneurial Intentions: A Career Anchor Perspective. Journal of Business Venturing, 19(1), 7-28.

Lucky, E. I., \& Olusegun, A. I. (2011). Is Small and Medium Enterprises (SMEs) an Entrepreneurship. International Journal of Academic Research in Business and Social Sciences, 2(1), 324-340.

Malebana, J. (2014). Entrepreneurial intentions of South African Rural University Students: A Test of The Theory of Planned Behaviour. Journal of Economics and Behavioral Studies., 6(2), 130-143.

Morris, M. H., Lewis, P. S., \& Sexton, D. L. (1994). Reconceptualizing Entrepreneurship: An Input-Output Perspective. SAM Advanced Management Journal, 59(1), 21-31.

Nursito, S., \& Nugroho, S. J. A. (2013). Analisis Pengaruh Interaksi Pengetahuan Berwirausaha Dan Efikasi Diri Terhadap Intensi Berwirausaha. Kiat Bisnis, $5(2), 148-158$.

Parker, S. C. (2004). The Economics Of Self-Employment And Entrepreneurship. Cambridge: Cambridge University Press.

Philips, S. (2008). Refleksi Karakter Bangsa. Jakarta: Bumi Aksara.

Pratiwi, M. S. (2009). Hubungan Antara Kepercayaan Diri Dengan Minat Berwirausaha Pada Mahasiswa Fakultas Psikologi UNIKA Soegijapranoto Semester Akhir. Fakultas Psikologi UNIKA Semarang.

Priyanto. (2008). Pembentukan Jiwa Kewirausahaan. Bandung.

Rasli, A. M. (2013). Factors Affecting Entrepreneurial Intention Among Graduites Students of University Teknologi Malaysia. International Journal of Business and Social Science, 4(2), 182-188.

Sabharawati. (2017). Pengaruh Sikap dan Motivasi Terhadap Minat Berwirausaha Pada Mahasiswa Semester V di AMK YPK Yogyakarta. Jurnal Kajian Pendidikan Ekonomi Dan Ilmu Ekonomi, 2(1). 
Sarwoko. (2011). Kajian Empiris Entrepreneur Intention Mahasiswa. Jurnal Ekonomi Dan Bisnis, 16(2).

Scott, M. G., \& Twomey, D. F. (1988). The long-term Supply of Entrepreneurs: Students' Career Aspirations in Relation to Entrepreneurship. Journal of Small Business Management, 26(1), 35-13.

Sparks, P., Ajzen, I., \& Hall-box, T. (2002). Perceived Behavioral Control, SelfEfficacy, Locus of Control, and the Theory of Planned Behavior1, 665683.

Sumadi. (2017). Pengaruh Sikap Motivasi dan Lingkungan Terhadap Niat Berwirausaha. E-Journal Manajemen, 6(2), 1007-1029.

Suryana. (2011). Kewirausahaann Pedoman Praktis : Kiat dan Proses Menuju Sukses. Jakarta: Salemba Empat.

Tubbs, M. E., \& Ekeberg, S. E. (1991). The Role of Intentions in Work Motivation: Implications for Goal Setting Theory and Research. Academy of Management Review, 16(1).

Widayoko. (2016). Pengaruh Efikasi Diri, Norma Subyektif, Sikap Berperilaku, Dan Pendidikan Berwirausaha Terhadap Intensi Berwirausaha Mahasiswa Fakultas Ekonomi Universitas Negeri Yogyakarta.

Winarsih. (2014). Minat Berwirausaha Ditinjau Dari Motivasi Dan Sikap Berwirausaha Pada Mahasiswa Program Studi Pendidikan Akuntansi Fakultas Keguruan Dan Ilmu Pendidikan Universitas Muhammadiyah Surakarta Angkatan 2011/2012.

Yang, J. (2013). The Theory of Planed Behaviour and predictions of Entrepreneurial Intention Among Chinese Undergraduates. Scietific Journal Publisher Ltd, 41(3), 367-376. 